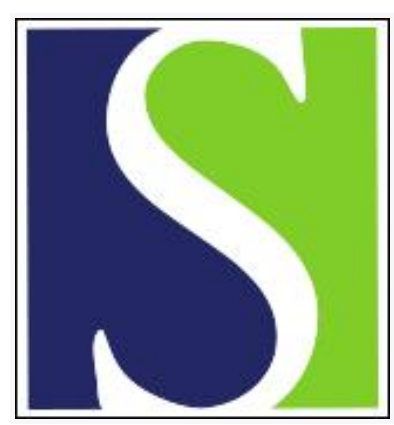

Scand J Work Environ Health 1994;20(4):243-250

https://doi.org/10.5271/sjweh.1401

Issue date: 01 Aug 1994

Asbestos exposure and the risk of lung cancer in a general urban population.

by Karjalainen A, Anttila S, Vanhala E, Vainio H

Affiliation: Finnish Institute of Occupational Health, Helsinki.

This article in PubMed: www.ncbi.nlm.nih.gov/pubmed/7801069

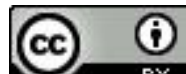




\title{
Asbestos exposure and the risk of lung cancer in a general urban population
}

\author{
by Antti Karjalainen, MD, ${ }^{1}$ Sisko Anttila, MD, ${ }^{1}$ Esa Vanhala, MSc, ${ }^{1}$ Harri Vainio, $\mathrm{MD}^{1,2}$
}

KARJALAINEN A, ANTTILA S, VANHALA E, VAINIO H. Asbestos exposure and the risk of lung cancer in a general urban population. Scand J Work Environ Health 1994;20:243-50.

\begin{abstract}
Овлестіves - The aim of the study was to investigate the asbestos-associated risk of lung cancer according to histological type of cancer, lobe of origin, pulmonary concentration, and type of amphibole fibers and also to estimate the etiologic fraction of asbestos for lung cancer.

METHODs - The pulmonary concentration of asbestos fibers in 113 surgically treated male lung cancer patients and 297 autopsy cases among men serving as referents was determined by scanning electron microscopy. The age- and smoking-adjusted odds ratios of lung cancer were calculated according to pulmonary fiber concentration for all lung cancer types, sqaumous-cell carcinoma, and adenocarcinoma and for the lower-lobe and the upper- and middle-lobe cancers.

Results - The risk of lung cancer was increased according to the pulmonary concentration of asbestos fibers (f) of 1.0 to $4.99 \cdot 10^{6} \mathrm{f} \cdot \mathrm{g}^{-1}$ [odds ratio (OR) 1.7] and $\geq 5.0 \cdot 10^{6} \mathrm{f} \cdot \mathrm{g}^{-1}$ (OR 5.3). The odds ratios associated with fiber concentrations of $\geq 1.0 \cdot 10^{6} \mathrm{f} \cdot \mathrm{g}^{-1}$ were higher for adenocarcinoma (OR 4.0) than for squamous-cell carcinoma (OR 1.6). The asbestos-associated risk was higher for lower lobe tumors than for upper lobe tumors. The risk estimates for anthophyllite and crocidolite-amosite fibers were similar, except for the risk of squamous-cell carcinoma. An etiologic fraction of 19\% was calculated for asbestos among male surgical lung cancer patients in the greater Helsinki area.

Conclusions - Past exposure to asbestos is a significant factor in the etiology of lung cancer in southern Finland. The asbestos-associated risk seems to be higher for pulmonary adenocarcinoma and lower-lobe tumors than for squamous-cell carcinoma and upper-lobe tumors.
\end{abstract}

KEY TERMS - amosite, anthophyllite, autopsy, crocidolite, electron microscopy, Finland.

Asbestos-related lung cancer is believed to be numerically the most important occupational cancer in the world (1). The frequencies of histological lung cancer types have varied among asbestos-exposed workers (2), but there is evidence that the asbestos-associated risk would be especially high for lung adenocarcinoma $(3,4)$.

Anthophyllite asbestos has been widely used in Finland due to its domestic production in 19181975. About $40 \%$ of all asbestos used in 1918-1988 consisted of anthophyllite (5). An increased risk of lung cancer has been reported among anthophyllite miners and millers $(6,7)$.

The objective of the present study was to estimate the proportion of lung cancers attributable to past asbestos exposure in Finland and to investigate the asbestos-associated risk by histological type, lobe of origin, and amphibole fiber type.

1 Finnish Institute of Occupational Health, Helsinki, Finland.

2 International Agency for Research on Cancer, Lyon, France.

Reprint requests to: Dr A Karjalainen, Finnish Institute of Occupational Health, Topeliuksenkatu 41 a A, FIN-00250 Helsinki, Finland.

\section{Subjects and methods}

\section{Surgical lung cancer patients}

The study population consisted of 135 lung cancer patients who underwent surgical lobectomy or pulmectomy in the Department of Thoracic and Cardiovascular Surgery at the Helsinki University Hospital between August 1988 and July 1993. Consecutively diagnosed lung cancer cases from two of the three surgical units of the Department were included. The mean age of the 113 men was 62.8 (range $35-81$ ) years, and the mean age of the 22 women was 61.3 (range $41-75$ ) years.

In each lung cancer case the histological cell type of lung cancer and the lobe of origin was determined from the surgical lung specimen and classified according to the 1981 classification of the World Health Organization. There were 67 squamous-cell carcinomas, 49 adenocarcinomas, 9 large-cell carcinomas, 9 small-cell carcinomas, and 1 adenosquamous carcinoma. There were 71 upper-lobe, 56 lower-lobe, and 6 middle-lobe cancers. In two cases the lobe of origin could not be defined due to the large size of the tumor.

The presence of histological diffuse interstitial fibrosis compatible with asbestosis was determined from the surgical lung specimens. At least three tissue sections per lobe were evaluated. 


\section{Referents}

A series of autopsy cases served as the male referents. Lung tissue samples were collected as a part of a large study on sudden deaths among men. This series comprised all sudden, unexpected deaths of men aged 35 to 69 years who had died in Helsinki and were autopsied between 15 January 1991 and 30 January 1992 at the Department of Forensic Medicine, University of Helsinki. Cases in which the body was combusted or macerated were excluded. Two men aged 33 years were inadvertently included. The autopsy series comprised $30 \%$ of all deaths among men in this age group in Helsinki.

The distribution of the causes of death among the referents is shown in table 1 . About $60 \%$ of the deaths were due to a disease, including ischemic heart disease (85 cases), other cardiovascular diseases (37 cases), respiratory diseases (13 cases), cerebrovascular diseases ( 10 cases), hepatic diseases ( 8 cases), malignant neoplasms ( 5 cases), gastrointestinal diseases ( 6 cases), neurologic diseases (5 cases), deaths due to chronic alcoholism (4 cases), metabolic disease ( 2 cases), and urologic disease ( 1 case). There were no deaths due to mesothelioma or asbestosis. Two of the deaths were due to lung cancer, and in one additional case lung cancer was diagnosed but was not the primary cause of death. These lung cancer cases were excluded from the original series of 300 autopsy cases; the reference group thus consisted of 297 men. We performed analyses both using all 297 referents and using only those 176 cases in which the death was due to a disease. As the results were similar, only the results for all 297 referents are presented. No reference group was available for the female lung cancer patients.

\section{Random lung cancer patients}

As the results of the study are based on the lung burden analyses of the aforementioned surgical lung cancer series, they may not be generalizable to non-

Table 1. Causes of death for 297 autopsy cases among Finnish men.

\begin{tabular}{lrrr}
\hline \multirow{2}{*}{ Cause of death } & N & \multicolumn{2}{c}{ Age (years) } \\
\cline { 3 - 4 } & & Range & Mean \\
\hline Disease & 176 & $36-69$ & 54.7 \\
Suicide & 52 & $33-69$ & 48.7 \\
Accidenta & 41 & $35-65$ & 48.3 \\
Alcohol intoxication & 21 & $36-62$ & 47.7 \\
Not defined & 7 & $37-69$ & 46.6 \\
\hline All & 297 & $33-69$ & 52.1 \\
\hline
\end{tabular}

a Includes 18 cases of accidental poisoning, 14 cases of accidental falling, 3 homicides, 2 cases of accidental suffocation, 2 traffic accidents, 1 case of accidental explosion, and 1 case of hypothermia.

b Could not be defined whether the death was due to accident or suicide. surgical lung cancer patients. To estimate possible differences in the distribution of occupational exposure to asbestos, we compared the occupational histories of the surgical lung cancer patients with the occupational histories of a random lung cancer series. This series comprised 178 lung cancer patients diagnosed consecutively between June 1990 and May 1991 at three local pulmonary clinics of the Helsinki University Hospital (Kiljava Hospital, Laakso Hospital, and Meltola Hospital). The mean age of the 148 men was 67.4 (range $46-82$ ) years, and that of the 30 women 67.5 (range $47-87$ ) years. According to data from the clinical patient records, there were 74 squamous-cell carcinomas, 37 small-cell carcinomas, 34 adenocarcinomas, 21 large-cell carcinomas, and 12 pulmonary malignancies without specified histology. This random lung cancer series contained 13 patients in common with the surgical lung cancer series.

\section{Electron microscopy}

The tissue pieces for the fiber analysis by electron microscopy were taken from the peripheral part of the lung, not including pleural or tumor tissue. The lung tissue samples of the referents were taken from the left upper lobe. The samples of the lung cancer patients, in cases of lobectomy, were taken from the lobe where the tumor was situated. In cases of bilobectomy or pulmectomy, the sample was taken from the lobe which appeared to be closest to normal (with the least amount of emphysema or pneumonia).

A tissue piece of about $100 \mathrm{mg}$ (wet weight) was taken for the fiber analysis. A low-temperature ashing technique was used to remove organic tissue. Fibers (f) were detected with a JEOL 100 CX-ASID4D electron microscope in the scanning mode (8). A length-to-width ratio of $>3$ and roughly parallel sides were used as the fiber criteria. A magnification of $5000 \times$ was used in the counting. Fibers longer than $1 \mu \mathrm{m}$ could be detected. A minimum of 200 viewing fields were evaluated to find at least 4 to 30 fibers per sample, depending on the density. With this procedure an analytical sensitivity (one fiber per sample) of about $0.07 \cdot 10^{6} \mathrm{f} \cdot \mathrm{g}$ dry tissue ${ }^{-1}$ could be reached. According to Poisson statistics, this value corresponds to a detection limit of $<0.3 \cdot 10^{6} \mathrm{f} \cdot \mathrm{g}^{-1}$ (four times the analytical sensitivity).

An energy dispersive X-ray microanalyzer (Tracor TN 5500) was used to determine the fiber type by comparing peak ratios to standard spectra. Amosite and crocidolite have almost similar X-ray spectra and are distinguished poorly. Therefore their data have not been presented separately. In a study on Finnish lung cancer patients, crocidolite fibers accounted for the great majority of amosite-crocidolite fibers identified with transmission electron microscopy (9). Chrysotile fibers are poorly detected by scanning electron microscopy, and consequently 
the results represent the concentration of amphibole fibers. Tremolite concentrations exceeding 0.3 . $10^{6} \mathrm{f} \cdot \mathrm{g}^{-1}$ were detected in nine samples. Chrysotile and tremolite fibers have been included in the number of total asbestos fibers, but their data have not been reported separately. The fiber analyses were carried out by a person who was unaware of the casereferent status of the samples.

\section{Occupational history}

The lung cancer patients were interviewed personally about their complete, chronological occupational history, including past occupational, domestic, and environmental exposure to asbestos. The interview was carried out during their stay in the hospital. Special attention was focused on the detailed description, occurrence, duration, and years of work and tasks with definite or probable exposure to asbestos or other occupational carcinogens. The surgical and random lung cancer patients were interviewed by the same interviewer.

The probability of past occupational exposure to asbestos was evaluated by two occupational hygienists by consensus and without any knowledge of the asbestos counts from the tissue samples. An exposure time of one month was regarded as minimum. The exposure was classified into four categories according to the following guidelines: Definite exposure (group 1): employment in mining asbestos, manufacturing asbestos products, insulating with asbestos, or demolishing old buildings; probable exposure (group 2): employment in shipyards, the construction industry, or metal workshops; possible exposure (group 3): employment in various trades with exposure to dust, such as mining, power plants, transportation, or the pulp and paper industry; unlikely or unknown exposure (group 4): employment in occupations with no known exposure to asbestos. In addition, the frequency and duration of tasks with at least probable exposure to asbestos were considered in the classification.

\section{Smoking habits}

The information on the smoking habits of the lung cancer patients came from a personal interview. The smoking habits of the referents were recorded in an interview of one of the relatives. A relative suitable and willing for the interview was available for only 166 of the 297 referents. For $94 \%$ of these 166 cases the widow, a child, one of the parents, or one of the sisters or brothers was interviewed. Two of the male and two of the female lung cancer patients were nonsmokers; the rest were either current or ex-smokers. About $18 \%$ of the referents were nonsmokers.

\section{Statistical analyses}

The odds ratios (OR) and their confidence intervals (CI) were calculated with logistic regression. Adjust- ment for age (four classes) and smoking-years (five classes) were used. The etiologic fraction (population attributable risk) was calculated by multiplying the proportion of exposed cases of all the cases by the term (RR-1)/RR. The age-adjusted odds ratios were used as estimates of the risk ratio (RR).

\section{Results}

Table 2 shows the age-adjusted odds ratios of lung cancer according to asbestos exposure as estimated from the pulmonary fiber counts. The risk estimate was greater for high fiber counts $\left(\geq 5 \cdot 10^{6} \mathrm{f} \cdot \mathrm{g}^{-1}\right)$ than for intermediate fiber counts $\left(1.0-4.99 \cdot 10^{6} \mathrm{f} \cdot \mathrm{g}^{-1}\right)$. The risk estimates were similar for anthophyllite and crocidolite-amosite fibers. When the two exposed categories were combined, an age-adjusted odds ratio of $2.3(95 \%$ CI $1.3-3.9, \mathrm{P}=0.004)$ was calculated for asbestos fiber counts of $\geq 1.0 \cdot 10^{6} \mathrm{f} \cdot \mathrm{g}^{-1}$. This value gives an etiologic fraction of $19 \%$ for asbestos among male lung cancer patients. The risk estimates of table 2 give an etiologic fraction of $9.8 \%$ for $1-4.99 \cdot 10^{6} \mathrm{f} \cdot \mathrm{g}^{-1}$ and $9.3 \%$ for $\geq 5.0$. $10^{6} \mathrm{f} \cdot \mathrm{g}^{-1}$ in lung tissue.

Two of our patients had been previously diagnosed as suffering from asbestosis, and in seven additional cases mild histological fibrosis compatible with asbestosis was detected in the surgical lung specimen. When the cases with clinical asbestosis or histological indication of fibrosis compatible with asbestosis were excluded, an increased risk of lung cancer was still associated with asbestos fiber concentrations of $\geq 5.0 \cdot 10^{6} \mathrm{f} \cdot \mathrm{g}^{-1}$ (age-adjusted OR 2.8, $95 \%$ CI $0.9-8.7, \mathrm{P}=0.07$ ) and asbestos fiber concentrations of $1.0-4.99 \cdot 10^{6} \mathrm{f} \cdot \mathrm{g}^{-1}(\mathrm{OR} 1.5,95 \% \mathrm{CI}$ $0.8-2.9, \mathrm{P}=0.19$ ).

The risk was elevated for both adenocarcinoma and squamous-cell carcinoma, but the risk estimate was greater and statistically significant only for adenocarcinoma (table 2). For the men with a pulmonary fiber concentration exceeding or equaling $1 \cdot 10^{6} \mathrm{f}$. $\mathrm{g}^{-1}$, about $44 \%$ of the lung cancers were adenocarcinomas versus $27 \%$ of adenocarcinomas among those with less than $1 \cdot 10^{6} \mathrm{f} \cdot \mathrm{g}^{-1}$ in lung tissue. Among the 22 female lung cancer patients the distribution pattern was different. None of them showed an elevated pulmonary fiber concentration $\left(\geq 1 \cdot 10^{6} \mathrm{f} \cdot \mathrm{g}^{-1}\right)$; yet $55 \%$ of the lung cancers were adenocarcinomas (table 3). The asbestos-associated odds ratios were higher for lower-lobe cancer than for cancers of the upper-middle lobe (table 4).

Smoking habits were known for 166 of the referents. The smoking-adjusted risk estimates for asbestos exposure (tables 2 and 4), acquired for only referents with known smoking habits, were similar to the smoking-unadjusted risk estimates.

Lung tissue samples were not available for the random lung cancer patients. Table 5 shows the distribution into exposure categories according to the eval- 
Table 2. Age-adjusted odds ratio $(\mathrm{OR})$ for lung cancer according to pulmonary fiber type and fiber concentration in 113 male lung cancer patients and 297 referents. $(95 \% \mathrm{Cl}=95 \%$ confidence interval)

\begin{tabular}{|c|c|c|c|c|c|c|}
\hline Cancer type & $\begin{array}{l}\text { Number } \\
\text { of cases }\end{array}$ & $\begin{array}{c}\text { Number } \\
\text { of referents }\end{array}$ & $\begin{array}{l}\text { Age. } \\
\text { adjusted } \\
\text { OR }\end{array}$ & $\begin{array}{c}95 \% \mathrm{Cl} \\
\text { for the } \\
\text { age-adjusted } \\
\text { OR }\end{array}$ & P-value & $\mathrm{OR}_{2}{ }^{\mathrm{a}}$ \\
\hline \multicolumn{7}{|c|}{ All histological cancer types } \\
\hline \multicolumn{7}{|c|}{ Total asbestos $\left(10^{6} \mathrm{f} \cdot \mathrm{g}^{-1}\right)$} \\
\hline $\begin{array}{l}<1.0 \\
1.0 \text { to } 4.99 \\
\geq 5.0\end{array}$ & $\begin{array}{l}74 \\
26 \\
13\end{array}$ & $\begin{array}{r}246 \\
44 \\
7\end{array}$ & $\begin{array}{l}1.0 \\
1.7 \\
5.3\end{array}$ & $\begin{array}{c}\text { Reference } \\
0.9-3.2 \\
1.9-14.8\end{array}$ & $\begin{array}{l}0.08 \\
0.001\end{array}$ & $\begin{array}{l}1.0 \\
1.7 \\
5.3\end{array}$ \\
\hline \multicolumn{7}{|c|}{ Anthophyllite ${ }^{b}\left(10^{6} \mathrm{f} \cdot \mathrm{g}^{-1}\right)$} \\
\hline $\begin{array}{l}<1.0 \\
\geq 1.0\end{array}$ & $\begin{array}{l}89 \\
24\end{array}$ & $\begin{array}{r}272 \\
25\end{array}$ & $\begin{array}{l}1.0 \\
2.0\end{array}$ & $\begin{array}{c}\text { Reference } \\
1.0-4.0\end{array}$ & 0.05 & $\begin{array}{l}1.0 \\
2.1\end{array}$ \\
\hline \multicolumn{7}{|c|}{ Crocidolite-amosite $\left(10^{6} \mathrm{f} \cdot \mathrm{g}^{-1}\right)$} \\
\hline $\begin{array}{l}<1.0 \\
\geq 1.0\end{array}$ & $\begin{array}{l}96 \\
17\end{array}$ & $\begin{array}{r}274 \\
23\end{array}$ & $\begin{array}{l}1.0 \\
1.9\end{array}$ & $\begin{array}{c}\text { Reference } \\
0.9-4.1\end{array}$ & 0.10 & $\begin{array}{l}1.0 \\
1.7\end{array}$ \\
\hline \multicolumn{7}{|l|}{ Adenocarcinoma } \\
\hline \multicolumn{7}{|c|}{ Total asbestos $\left(10^{6} \mathrm{f} \cdot \mathrm{g}^{-1}\right)$} \\
\hline $\begin{array}{l}<1.0 \\
\geq 1.0\end{array}$ & $\begin{array}{l}20 \\
17\end{array}$ & $\begin{array}{r}246 \\
51\end{array}$ & $\begin{array}{l}1.0 \\
4.0\end{array}$ & $\begin{array}{l}\text { Reference } \\
1.8-8.6\end{array}$ & $<0.001$ & $\begin{array}{l}1.0 \\
4.2\end{array}$ \\
\hline \multicolumn{7}{|c|}{ Anthophyllite $\left(10^{6} \mathrm{f} \cdot \mathrm{g}^{-1}\right)$} \\
\hline $\begin{array}{l}<1.0 \\
\geq 1.0\end{array}$ & $\begin{array}{l}25 \\
12\end{array}$ & $\begin{array}{r}272 \\
25\end{array}$ & $\begin{array}{l}1.0 \\
3.7\end{array}$ & $\begin{array}{c}\text { Reference } \\
1.4-9.3\end{array}$ & 0.007 & $\begin{array}{l}1.0 \\
3.7\end{array}$ \\
\hline \multicolumn{7}{|c|}{ Crocidolite-amosite $^{c}\left(10^{6} f \cdot g^{-1}\right)$} \\
\hline $\begin{array}{l}<1.0 \\
\geq 1.0\end{array}$ & $\begin{array}{l}27 \\
10\end{array}$ & $\begin{array}{r}274 \\
23\end{array}$ & $\begin{array}{l}1.0 \\
3.1\end{array}$ & $\begin{array}{c}\text { Reference } \\
1.1-8.2\end{array}$ & 0.03 & $\begin{array}{l}1.0 \\
2.9\end{array}$ \\
\hline \multicolumn{7}{|c|}{ Squamous-cell carcinoma } \\
\hline \multicolumn{7}{|c|}{ Total asbestos $\left(10^{6} \mathrm{f} \cdot \mathrm{g}^{-1}\right)$} \\
\hline $\begin{array}{l}<1.0 \\
\geq 1.0\end{array}$ & $\begin{array}{l}43 \\
18\end{array}$ & $\begin{array}{r}246 \\
51\end{array}$ & $\begin{array}{l}1.0 \\
1.6\end{array}$ & $\begin{array}{c}\text { Reference } \\
0.8-3.3\end{array}$ & 0.17 & $\begin{array}{l}1.0 \\
1.5\end{array}$ \\
\hline \multicolumn{7}{|c|}{ Anthophyllite ${ }^{b}\left(10^{6} f \cdot g^{-1}\right)$} \\
\hline $\begin{array}{l}<1.0 \\
\geq 1.0\end{array}$ & $\begin{array}{l}50 \\
11\end{array}$ & $\begin{array}{r}272 \\
25\end{array}$ & $\begin{array}{l}1.0 \\
1.8\end{array}$ & $\begin{array}{c}\text { Reference } \\
0.7-4.2\end{array}$ & 0.20 & $\begin{array}{l}1.0 \\
1.7\end{array}$ \\
\hline \multicolumn{7}{|c|}{ Crocidolite-amosite $\left(10^{6} \mathrm{f} \cdot \mathrm{g}^{-1}\right)$} \\
\hline $\begin{array}{l}<1.0 \\
\geq 1.0\end{array}$ & $\begin{array}{r}56 \\
5\end{array}$ & $\begin{array}{r}274 \\
23\end{array}$ & $\begin{array}{l}1.0 \\
0.9\end{array}$ & $\begin{array}{c}\text { Reference } \\
0.3-2.9\end{array}$ & 0.91 & $\begin{array}{l}1.0 \\
0.8\end{array}$ \\
\hline
\end{tabular}

a $\mathrm{OR}_{2}$ adjusted for age and smoking years with the use of 166 referents with known smoking habits.

b Adjusted for age and pulmonary concentration of crocidolite-amosite fibers.

c Adjusted for age and pulmonary concentration of anthophyllite fibers.

Table 3. Distribution of histological lung cancer types according to pulmonary concentration of asbestos fibers among 113 male and 22 female surgically treated lung cancer patients.

\begin{tabular}{lccccc}
\hline $\begin{array}{l}\text { Fiber concentration } \\
\text { in lung tissue }\end{array}$ & \multicolumn{5}{c}{ Histological cell type of lung cancer } \\
\cline { 2 - 6 } & $\begin{array}{c}\text { Squamous-cell } \\
\text { carcinoma }\end{array}$ & $\begin{array}{c}\text { Adeno- } \\
\text { carcinoma }\end{array}$ & $\begin{array}{c}\text { Large-cell } \\
\text { carcinoma }\end{array}$ & $\begin{array}{c}\text { Small-cell } \\
\text { carcinoma }\end{array}$ & $\begin{array}{c}\text { Adenosquamous } \\
\text { carcinoma }\end{array}$ \\
\hline$<1.0 \cdot 10^{6} \mathrm{f} \cdot \mathrm{g}^{-1}$ & 43 & 20 & 5 & 6 & - \\
$\quad \begin{array}{l}\text { Men } \\
\text { Women }\end{array}$ & 6 & 12 & 2 & 2 & - \\
$\geq 1.0 \cdot 10^{6} \mathrm{f} \cdot \mathrm{g}^{-1}$ & 18 & 17 & 2 & 1 & 1 \\
$\quad \begin{array}{l}\text { Men } \\
\text { Women }\end{array}$ & - & - & - & - & - \\
\hline
\end{tabular}

uation of occupational histories in the surgical and random lung cancer series. The distribution was similar in the two patient series. Among the surgical lung cancer patients concentrations of $\geq 1.0 \cdot 10^{6} \mathrm{f} \cdot \mathrm{g}^{-1}$ were detected in $79 \%$ of those with definite, $41 \%$ of those with probable, $25 \%$ of those with possible, and $7 \%$ of those with unlikely exposure (table 6). Among the 39 patients with a concentration of at least $1 \cdot 10^{6}$ $\mathrm{f} \cdot \mathrm{g}^{-1}$ there were one asbestos factory worker and four men who had done insulation work. The rest had 
Table 4. Age-adjusted odds ratio (OR) for lung cancer according to lobe of origin of cancer and pulmonary concentration of asbestos fibers in 111 male lung cancer patients and 297 referents. $(95 \% \mathrm{Cl}=95 \%$ confidence interval)

\begin{tabular}{|c|c|c|c|c|c|c|}
\hline Lobe of origin & $\begin{array}{l}\text { Number } \\
\text { of cases }\end{array}$ & $\begin{array}{l}\text { Number } \\
\text { of referents }\end{array}$ & $\begin{array}{c}\text { Age-adjusted } \\
\text { OR }\end{array}$ & $\begin{array}{c}95 \% \mathrm{Cl} \\
\text { of the } \\
\text { age-adjusted } \\
\text { OR }\end{array}$ & P-value & $\mathrm{OR}_{2}^{\mathrm{a}}$ \\
\hline \multicolumn{7}{|l|}{ Lower lobe } \\
\hline $\begin{array}{l}<1.0 \cdot 10^{6} \cdot \mathrm{g}^{-1} \\
1.0 \text { to } 4.99 \cdot 10^{6} \cdot \mathrm{g}^{-1} \\
\geq 5.0 \cdot 10^{6} \cdot \mathrm{g}^{-1}\end{array}$ & $\begin{array}{r}27 \\
14 \\
8\end{array}$ & $\begin{array}{r}246 \\
44 \\
7\end{array}$ & $\begin{array}{l}1.0 \\
2.8 \\
8.0\end{array}$ & $\begin{array}{c}\text { Reference } \\
1.2-6.2 \\
2.4-26.5\end{array}$ & $\begin{array}{c}0.01 \\
<0.001\end{array}$ & $\begin{array}{l}1.0 \\
2.8 \\
7.7\end{array}$ \\
\hline \multicolumn{7}{|l|}{ Upper or middle lobe } \\
\hline $\begin{array}{l}<1.0 \cdot 10^{6} \cdot \mathrm{g}^{-1} \\
1.0 \text { to } 4.99 \cdot 10^{6} \cdot \mathrm{g}^{-1} \\
\geq 5.0 \cdot 10^{6} \cdot \mathrm{g}^{-1}\end{array}$ & $\begin{array}{r}45 \\
12 \\
5\end{array}$ & $\begin{array}{r}246 \\
44 \\
7\end{array}$ & $\begin{array}{l}1.0 \\
1.2 \\
3.2\end{array}$ & $\begin{array}{l}\text { Reference } \\
0.6-2.6 \\
0.9-11.3\end{array}$ & $\begin{array}{l}0.61 \\
0.07\end{array}$ & $\begin{array}{l}1.0 \\
1.0 \\
3.9\end{array}$ \\
\hline
\end{tabular}

a $\mathrm{OR}_{2}$ adjusted for age and smoking years with the use of 166 referents with known smoking habits.

Table 5. Occupational exposure to asbestos among 135 surgical and 178 random Finnish lung cancer patients.

\begin{tabular}{lcccc}
\hline \multirow{2}{*}{ Exposure group } & \multicolumn{2}{c}{ Surgical lung cancer series } & \multicolumn{2}{c}{ Random lung cancer series } \\
\cline { 2 - 5 } & \begin{tabular}{c} 
Men $\begin{array}{c}\mathrm{N}=113) \\
(\%)\end{array}$ \\
\cline { 2 - 5 }
\end{tabular} & $\begin{array}{c}\text { Women }(\mathrm{N}=22) \\
(\%)\end{array}$ & $\begin{array}{c}\text { Men }(\mathrm{N}=148) \\
(\%)\end{array}$ & $\begin{array}{c}\text { Women }(\mathrm{N}=30) \\
(\%)\end{array}$ \\
\hline Definite exposure & 12.4 & 0 & 13.5 & 0 \\
Probable exposure & 32.7 & 0 & 33.1 & 0 \\
Possible exposure & 31.9 & 18.2 & 31.8 & 30.0 \\
Unlikely exposure & 23.0 & 81.8 & 21.6 & 70.0 \\
\hline
\end{tabular}

been exposed in construction, shipyard, or maintenance work.

\section{Discussion}

An elevated risk of lung cancer, with an indication of a dose-response, was associated with increased pulmonary fiber concentrations. The comparisons of smoking-adjusted and unadjusted risk estimates did not indicate that the results were biased by differences in the smoking habits between the exposed and unexposed subjects. The smoking habits were not known for all the referents, however, and a complete adjustment for smoking could thus not be done. Further difficulties in the adjustment of the effect of tobacco smoking were caused by the small number (two cases) of nonsmokers among the male lung cancer patients. Hence, the lowest smoking category used in the analyses not only contained nonsmokers, but also smokers with less than 20 smoking-years. The accuracy of the information given by the relatives of the referents on smoking-years may have also been less than that given by the lung cancer patients in their personal interview. Yet it is unlikely that these methodological inaccuracies would explain the risk estimates associated with past asbestos exposure.

As estimated from the occupational histories, the past exposure to asbestos was similar between the surgical and random lung cancer patients. This finding suggests that there were no major differences in
Table 6. Pulmonary concentration of asbestos fibers according to probability of occupational exposure to asbestos among 135 Finnish surgical lung cancer patients.

\begin{tabular}{|c|c|c|c|c|}
\hline \multirow{2}{*}{$\begin{array}{l}\text { Exposure } \\
\text { category }\end{array}$} & \multirow{2}{*}{$\begin{array}{c}\text { Number } \\
\text { of } \\
\text { patients }\end{array}$} & \multicolumn{3}{|c|}{$\begin{array}{c}\text { Pulmonary concentration } \\
\text { of asbestos fibers }\left(10^{6} f \cdot \mathrm{g}^{-1}\right) \\
\end{array}$} \\
\hline & & Range & Median & $\begin{array}{l}\geq 1.0 \\
(\%)\end{array}$ \\
\hline $\begin{array}{l}\text { Definite } \\
\text { Probable } \\
\text { Possible } \\
\text { Unlikely }\end{array}$ & $\begin{array}{l}14 \\
37 \\
40 \\
44\end{array}$ & $\begin{aligned} & 0.5-150 \\
< & 0.3-13 \\
< & 0.3-4.5 \\
< & 0.3-1.9\end{aligned}$ & $\begin{array}{r}5.6 \\
0.6 \\
0.3 \\
<0.3\end{array}$ & $\begin{array}{r}79 \\
41 \\
25 \\
7\end{array}$ \\
\hline
\end{tabular}

the exposure between the surgical and random lung cancer patients. Among the surgical lung cancer patients there was, however, an overlap in the pulmonary fiber concentrations between the exposure categories, especially between groups of probable and possible exposure. This finding implies that the pulmonary fiber concentration and the occupational history classification are not identical exposure indicators. The differences in the distribution of histological types between the two cancer series also indicate that the results of the surgical lung cancer series may not be generalizable to apply to all lung cancers, especially in respect to small-cell cancer. In previous studies the etiologic fraction of asbestos in a random lung cancer series was $6 \%$ in Glasgow and the west of Scotland, $20 \%$ in Trieste, Italy, $23 \%$ in Telemark, Norway, and $16 \%$ in Göteborg, Sweden (10-13). It must be emphasized that, when the eti- 
ologic fraction is equated with the expected change in disease load following the removal of a risk factor, it is supposed that the relationship between the factor and the disease is causal and not only statistical. In the case of asbestos and lung cancer a causal relationship is reasonably well established, and the etiologic fraction is a relevant measure when prevention strategies are evaluated. When etiologic fractions are interpreted, it must, however, be emphasized that, due to the combined effect of smoking and occupational carcinogens, the sum of the epidemiologically calculated etiologic fractions of different agents in a given population usually exceeds $100 \%$. The use of the etiologic fraction also involves terminological and conceptual problems and usually requires specific assumptions about exposure action and interactions (14).

In previous studies of several asbestos-exposed cohorts, the ratio of excess cases of lung cancer to mesothelioma cases has varied from 1:1 to 10:1 $(1,15)$. During the five-year period from 1987 to 1991, there were 34 cases of mesothelioma among men in Helsinki according to the statistics of the Finnish Cancer Registry. This value would correspond to 34 to 340 excess cases of lung cancer, which is 3.9 to $39 \%$ of the 872 lung cancer cases among men during the same period of time in Helsinki. Our estimate of $19 \%$ among male surgical lung cancer patients is within this range. The corresponding proportion for other parts of Finland is probably lower, as the use of asbestos was more extensive and the number of exposed construction, shipyard, and industry workers was higher in Helsinki and the surrounding area than in other parts of Finland. This result is reflected by the age-adjusted incidence rate of mesothelioma among men in 1987-1991, which, according to statistics of the Finnish Cancer Registry, was 9 per million men in Finland as compared with 23 per million men in Helsinki. If we assume that the regional differences in the diagnostics of mesothelioma are minor, these figures suggest that the asbestos-attributable fraction of all Finnish lung cancers among men may be less than half of our estimate for the greater Helsinki area.

Most of the exposed lung cancer patients had been exposed in construction, shipyard, or maintenance work. Exposure during the use of asbestos products in construction and shipyard work and indirect exposure during insulation work and asbestos spraying are thus not to be neglected when the health hazards of asbestos and their prevention are evaluated. In such cases it is often difficult to assess the intensity of past exposure on the basis of the work history and exposure interview, and crucial information of the individual exposure can be gained from a pulmonary fiber analysis. When pulmonary fiber analyses are used at the individual level, it may be preferable to use several samples from different parts of the lung to improve the analytical reliability. A wide varia- tion in the fiber counts has been observed in interlaboratory comparisons, and laboratory-bound reference values should be used (16). Despite the obvious advantages of the pulmonary fiber analysis, it should be stressed that a complete work history with special emphasis on jobs and tasks with probable or definite exposure to asbestos is the most important exposure indicator, and actually the only way to estimate latency.

Chrysotile is cleared more rapidly from the lungs than amphiboles, and, even if transmission electron microscopy is used, the chrysotile content of lung tissue is not an equally representative measure of past cumulative chrysotile exposures as is the amphibole content for amphibole exposures $(17,18)$. As about $40 \%$ of all asbestos used in Finland during 19181988 consisted of amphiboles (5) and a mixed exposure to chrysotile and amphiboles took place in most of the industrial applications, the amphibole content in the lung tissue is probably a reasonably representative indicator of past exposure to asbestos in Finland. In cases with main exposure to chrysotile these methodological problems must, however, be recognized. The use of occupational history as an exposure indicator in the risk analyses would not suffer from such problems. In our study the differences in the quality of occupational history data between the cases and the referents, however, did not allow us to do such analyses.

In our study the sample site for the fiber analysis among the lung cancer cases depended on which lobe or lobes were resected, whereas the tissue samples of the referents were all taken from the upper lobe. We assume that these fiber concentrations are comparable and equally representative of cumulative exposure to asbestos. In previous electron microscopy studies counting fibers of all sizes together, either no systematic differences or an indication of higher concentrations in the upper lobes than in the lower lobes has been found $(8,19-21)$. If the fiber concentration is higher in the upper lobes, our method would have underestimated the exposure of lower-lobe lung cancer cases and thus also the asbestos-associated risk estimates.

The absence of elevated pulmonary fiber concentrations and exposure histories indicating probable or definite exposure to asbestos among the 22 female surgical and 30 random lung cancer patients suggests that the proportion of lung cancers attributable to asbestos is much lower among women than among men. This observation reflects the low proportion of female workers in the construction. shipyard, and asbestos industries. This result is also in accordance with the statistics of the Finnish Registry of Occupational Diseases; in 1987-1991 129 and 4 cases of asbestos-related lung cancer were reported for the men and women, respectively. This ratio of men to women among the cases (about 32:1) is much higher than the about $4.5: 1$ ratio for men to women among all lung cancers in Finland during 1987- 
1991 (8601 men and 1905 women according to the statistics of the Finnish Cancer Registry).

Our results indicate that the asbestos-associated risk of lung cancer is higher for adenocarcinoma than for squamous-cell carcinoma. Because of the small number of patients, we were unable to draw any conclusions about the association between asbestos and small-cell or large-cell carcinoma. The higher risk of adenocarcinoma, as compared with squamous-cell carcinoma, is in agreement with the findings of previous studies among Danish and Swedish asbestos cement workers $(3,4)$, but also opposite results or reports with no difference in the risk have been published $(2,11,22)$. Different selection criteria between exposed and reference lung cancer cases (surgery, autopsy, bronchoscopy) and variation between pathologists in the typing of lung tumors may have confounded some of these studies (23-25). It thus remains controversial whether the asbestos-associated risk of lung cancer is greater for some histological cancer type or whether there are no differences in the risk. A difference in the risk between these cancer types would raise the question of a possible difference in the carcinogenic mechanisms. Both asbestos and smoking seem to be complex carcinogens which can affect more than one stage of lung carcinogenesis, and very limited information is available on the interaction between asbestos and smoking in causing specific histological types of lung cancer (26). It is interesting that in our study the proportion of adenocarcinomas was especially high among the female lung cancer patients (all unexposed to asbestos). This finding probably indicates that women have a lower incidence of tobacco-associated squamous-cell carcinomas rather than that they would have a higher incidence of adenocarcinoma. The difference in the asbestos-associated risk between lower- and upper-lobe tumors is compatible with the findings of our previous report (9).

There was an elevated risk of lung cancer associated with high pulmonary concentrations of asbestos fibers even after cases with histological indications of mild asbestosis were excluded. These findings support the view that asbestos increases the risk of lung cancer even in the absence of asbestosis. As for the cases with asbestosis, it is impossible to conclude whether the fibrosis and the lung cancer were independently caused by asbestos or whether the cancer was caused by the fibrosis. Most of the asbestosis cases were mild and could be detected in the histological examination only. It is doubtful whether such a mild case of fibrosis could have caused the cancer. Some of the exposed referents might have also had mild histological fibrosis compatible with asbestosis and should thus have been excluded from the aforementioned analysis. This exclusion would have increased the risk estimate. As the presence of histological fibrosis among the referents was not evaluated, no such exclusion could be done. It is noteworthy that six of the nine lung cancer patients with histological fibrosis (and heavy exposure) had an adenocarcinoma, two a squamous-cell carcinoma, and one a small-cell carcinoma.

Because of the small number of nonsmokers among the male lung cancer patients, it was not possible to compare the asbestos-associated risk between the nonsmokers and smokers. The two male nonsmokers in the lung cancer series were both unexposed to asbestos and had adenocarcinoma.

The use of pulmonary fiber concentrations as exposure indicators resulted in similar lung cancer risk estimates for anthophyllite and crocidolite-amosite fibers. This finding is in agreement with the lung cancer risks observed in previous studies among anthophyllite and crocidolite miners $(6,27,28)$. It is noteworthy that there is a clear difference in the risk of mesothelioma between these cohorts of anthophyllite and crocidolite miners. This difference could be due to the difference in the dimensional characteristics between these fiber types. It has been concluded that mesothelioma is the most closely associated with numbers of fibers longer than $5 \mu \mathrm{m}$ and thinner than $0.1 \mu \mathrm{m}$, whereas lung cancer is the most closely associated with numbers of fibers longer than $10 \mu \mathrm{m}$ and thicker than $0.15 \mu \mathrm{m}$ (29). In the present study the risk estimates of squamous-cell carcinoma were elevated for elevated anthophyllite concentrations but not for elevated crocidolite-amosite concentrations. This observation was based on a small number of cases and was not statistically significant. The distributions of histological lung cancer types in the cohorts of anthophyllite or crocidolite miners have not been reported.

\section{Acknowledgments}

We thank L Heikkilä, MD, P Karhunen, MD, K Lalu, $\mathrm{MD}$, and A Penttilä, MD, for their help with the collection of the material. We also thank P Kyyrönen, MSc, for his help with the statistical analyses, and A Tossavainen, DTech, and T Tuomi, DSc, for their help in classifying the occupational histories. We are grateful to E Pukkala, MSc, of the Finnish Cancer Registry and T Kauppinen, PhD, of the Finnish Registry of Occupational Diseases for the cancer statistics and to T Kaustia, MA, who did the linguistic revision of the manuscript. This work was supported by the Finnish Work Environment Fund and the Finnish Medical Society Duodecim.

\section{References}

1. Doll R, Peto R. The causes of cancer: quantitative estimates of avoidable risks of cancer in the United States today. Oxford: Oxford University Press, 1981.

2. Churg A. Lung cancer cell type and asbestos exposure. JAMA $1985 ; 253: 2984-5$.

3. Raffn E, Lynge E, Korsgaard B. Incidence of lung cancer by histological type among asbestos cement workers in Denmark. Br J Ind Med 1993;50:85-9. 
4. Johansson L, Albin M, Jakobsson K, Mikoczy Z. Histological type of lung carcinoma in asbestos cement workers and matched controls. Br J Ind Med 1992;49: $626-30$.

5. Ministry of Labour. Asbestikomitean mietintö [Report of the Asbestos Committee]. Helsinki, Ministry of Labour, 1989. Komiteanmietintö [Report series of the Governmental Committees] no 1989:66. English summary.

6. Meurman LO, Kiviluoto R, Hakama M. Mortality and morbidity among the working population of anthophyllite asbestos miners in Finland. $\mathrm{Br} \mathrm{J}$ Ind Med 1974; $31: 105-12$.

7. Meurman LO, Kiviluoto R, Hakama M. Combined effect of asbestos exposure and tobacco smoking on Finnish anthophyllite miners and millers. Ann NY Acad Sci 1979;330:491-5.

8. Tuomi T, Segerberg-Konttinen M, Tammilehto L, Tossavainen A, Vanhala E. Mineral fiber concentration in lung tissue of mesothelioma patients in Finland. Am J Ind Med 1989;16:247-54.

9. Anttila S, Karjalainen A, Taikina-aho O, Kyyrönen P, Vainio H. Lung cancer in the lower lobe is associated with pulmonary asbestos fiber count and fiber size. Environ Health Perspect 1993;101:166-70.

10. De Vos Irvine H, Lamont DW, Hole DJ, Gillis CR. Asbestos and lung cancer in Glasgow and the west of Scotland. Br Med J 1993;306:1503-6.

11. Bovenzi M, Stanta G, Antiga G, Peruzzo P, Cavallieri F. Occupational exposure and lung cancer risk in a coastal area of Northeastern Italy. Int Arch Occup Environ Health 1993;65:35-41.

12. Kjuus $H$, Langård $S$, Skjærven $R$. A case-referent study of lung cancer, occupational exposures and smoking: III. etiologic fraction of occupational exposures. Scand J Work Environ Health 1986;12:210_5.

13. Järvholm B, Larsson S, Hagberg S, Olling S, Ryd W, Torén K. Quantitative importance of asbestos as a cause of lung cancer in a Swedish industrial city: a case-referent study. Eur Respir J 1993;6:1271-5.

14. Robins JM, Greenland S. Estimability and estimation of excess and etiologic fractions. Statis Med 1989;8: $845-59$.

15. Health Effects Institute - Asbestos Research. Health implications of exposure to asbestos. In: Health Effects Institute - Asbestos Research. Asbestos in public and commercial buildings: a literature review and synthesis of current knowledge. Cambridge (United Kingdom): Health Effects Institute - Asbestos Research, 1991.

16. Gylseth B, Churg A, Davis JGM, Johnson N, Morgan A, Mowé G, et al. Analysis of asbestos fibers and asbestos bodies in tissue samples from human lung: an international interlaboratory trial. Scand J Work Environ Health 1985;11:107-10.
17. Churg A. Chrysotile, tremolite and malignant mesothelioma in man. Chest 1988;93:621-8.

18. Albin M, Johansson L, Pooley FD, Jakobsson K, Attewell R, Mitha R. Mineral fibres, fibrosis, and asbestos bodies in lung tissue from deceased asbestos cement workers. Br J Ind Med. 1990;47:767-74.

19. Sebastien P, Fondimare A, Bignon J, Monchaux G, Desbordes J, Bonnaud G. Topographic distribution of asbestos fibres in human lung in relation to occupational and non-occupational exposure. In: Walton WH, McGovern B, editors. Inhaled particles IV. New York, NY: Pergamon Press, 1977:435-44.

20. Churg A. The distribution of amosite asbestos in the periphery of the normal human lung. $\mathrm{Br} \mathrm{J}$ Ind Med 1990;47:677-81.

21. Woitowitz H-J, Rödelsperger K, Manke J, Bruckel B. Identification and quantification of asbestos and other mineral fibers in human lung tissue with analytical scanning electron microscopy (STEM). In: Bundesanstalt fur Arbeitsschutz. Schriftenreihe der Bundesanstalt fur Arbeitsschutz, Sonderschrift S27. Dortmund: Bundesanstalt fur Arbeitsschutz, 1988:1-86.

22. Kjuus $H$, Skjærven $R$, Langård $S$, Lien JT, Aamodt $T$. A case-referent study of lung cancer, occupational exposures and smoking: II. role of asbestos exposure. Scand J Work Environ Health 1986;12:203-9.

23. Whitwell F, Newhouse ML, Bennett DR. A study of the histological cell types of lung cancer in patients suffering from asbestosis in the United Kingdom. Br J Ind Med 1974;31:298-303.

24. Yesner R. Observer variability and reliability in lung cancer diagnosis. Cancer Chemother Rep 1973;4:557.

25. Ives JC, Buffler PA, Greenberg D. Environmental associations and histopathologic patterns of carcinoma of the lung. Am Rev Respir Dis 1983;128:195-209.

26. Vainio H, Boffetta P. Mechanisms of the combined effect of asbestos and smoking in the etiology of lung cancer. Scand J Work Environ Health 1994;20:23542 .

27. Hobbs MST, Woodward SD, Murphy B, Musk AW, Elder JE. The incidence of pneumoconiosis, mesothelioma, and other respiratory cancer in men engaged in mining and milling crocidolite in western Australia. In: Wagner JC, editor. Biological effects of mineral fibers. Lyon: International Agency for Research in Cancer (IARC), 1980:615-25. IARC scientific publications, no 30.

28. Armstrong BK, De Klerk NH, Musk AW, Hobbs MST. Mortality in miners and millers of crocidolite in Western Australia. Br J Ind Med 1988;45:5-13.

29. Lippmann M. Asbestos exposure indices. Environ Res 1988;46:86-106.

Received for publication: 18 January 1994 